\title{
Pengaruh Persepsi Harga, Varian, dan Kualitas Produk Terhadap Keputusan Pembelian Smartphone Xiaomi (Survey Persepsi Mahasiswa IBIK Bogor)
}

\author{
Odrick Helsar L. Tobing dan Budi Setiawan \\ Program Studi Manajemen, Institut Bisnis dan Informatika Kesatuan \\ E-Mail: budi@ibik.ac.id
}

Submitted: APRIL 2020

Accepted: AGUSTUS 2020

\begin{abstract}
This study aims to see if Perception Of Price, Variance and Products, and Quality Of Products affect bot partial and simultaneous Decision Of Purchase. The population in this study was a student of IBIK Bogor who once use Xiaomi's Smartphone in IBIK Bogor with 100 samples. The Slovin method used $a$ is a non-sampling method with an approximate sampling type. The result of this study are as follows: (1) a Partial Value perceotions affect the decision of the purchase with a higher value $T$ count than $T$ table(3.316> 1.94). (2) a partial Product Variant affects the decision of the purchase with value of T greater than T table (3,461> 1.94). (3) The Quality of The Product is partial to the decision of the Purchase with a value of T count greater than T table $(2.813>1.94)$. (4) Perceptions Of Price, Variance Of Products, and Quality Of Products Simultaneously have positive and significant effects on purchasing decisions with greater F count than F table (65.297> 3.09) and significant value of 0.000. (5) The three independent variables (Value Perceptions, Product Variant, and Product Quality) are able to explain variations in dependencies (Purchasing Decision) of $67,3 \%$, while $32,7 \%$ of purchasing decision are affected by other independent variables
\end{abstract}

Keywords: perceived price, products' varians, product quality, buying decision

\begin{abstract}
ABSTRAK
Penelitian ini bertujuan untuk mengetahui apakah Persepsi Harga, Varian Produk dan Kualitas Produk berpengaruh secara parsial dan simultan terhadap Keputusan Pembelian. Populasi dalam penelitian ini adalah mahasiswa IBIK Bogor yang pernah menggunakan Smartphone Xiaomi di IBIK Bogor dengan jumlah sampel sebanyak 100 orang. Metode slovin yang digunakan adalah metode non probability sampling dengan tipe purposive sampling. Metode analisis data meggunakan regresi linear berganda untuk mengetahui pengaruh Persepsi Harga, Varian Produk dan Kualitas Produk terhadap Keputusan Pembelian. Hasil dari penelitian ini adalah sebagai berikut: (1) Persepsi Harga secara parsial berpengaruh terhadap Keputusan Pembelian dengan nilai t hitung lebih besar dari t tabel $(3,316>1,94)$. (2) Varian Produk secara parsial berpengaruh terhadap Keputusan Pembelian dengan nilai t hitung lebih besar dari t tabel $(3,461>1,94)$. (3) Kualitas Produk secara parsial berpengaruh terhadap Keputusan Pembelian dengan nilai $t$ hitung lebih besar dari $t$ tabel $(2,813>1,94)$. (4) Persepsi Harga, Varian Produk dan Kualitas Produk secara simultan berpengaruh positif dan signifikan terhadap Keputusan Pembelian dengan nilai $\mathrm{F}$ hitung lebih besar dari $\mathrm{F}$ tabel $(65,297>3,09)$ dan nilai signifikansi sebesar 0.000. (5) Ketiga variabel independen (Persepsi Harga, Varian Produk dan Kualitas Produk) mampu menjelaskan variasi pada variabel dependen (Keputusan Pembelian) sebesar 67,3\%, sedangkan 32,7\% Keputusan Pembelian dipengaruhi oleh variabel independen lainnya.
\end{abstract}

Kata Kunci: persepsi harga, varian produk, kualitas produk, keputusan pembelian

\section{JIMKES}

Jurnal Ilmiah Manajemen Kesatuan Vol. 8 No. 2, 2020 pp. $95-104$
IBI Kesatuan ISSN $2337-7860$ E-ISSN 2721 - 169X 
Customer Buying

Decision and

Product's Attributes

\section{PENDAHULUAN}

Perkembangan teknologi telekomunikasi di Indonesia saat ini mengalami kemajuan yang sangat pesat, hal ini ditunjukkan dari jumlah pengguna smartphone yang terus meningkat. Pilihan konsumen pada smartphone semakin beragam. Saat ini smartphone smartphone tidak lagi dianggap sebagai barang mewah, tetapi sudah menjadi kebutuhan dasar hampir semua individu.

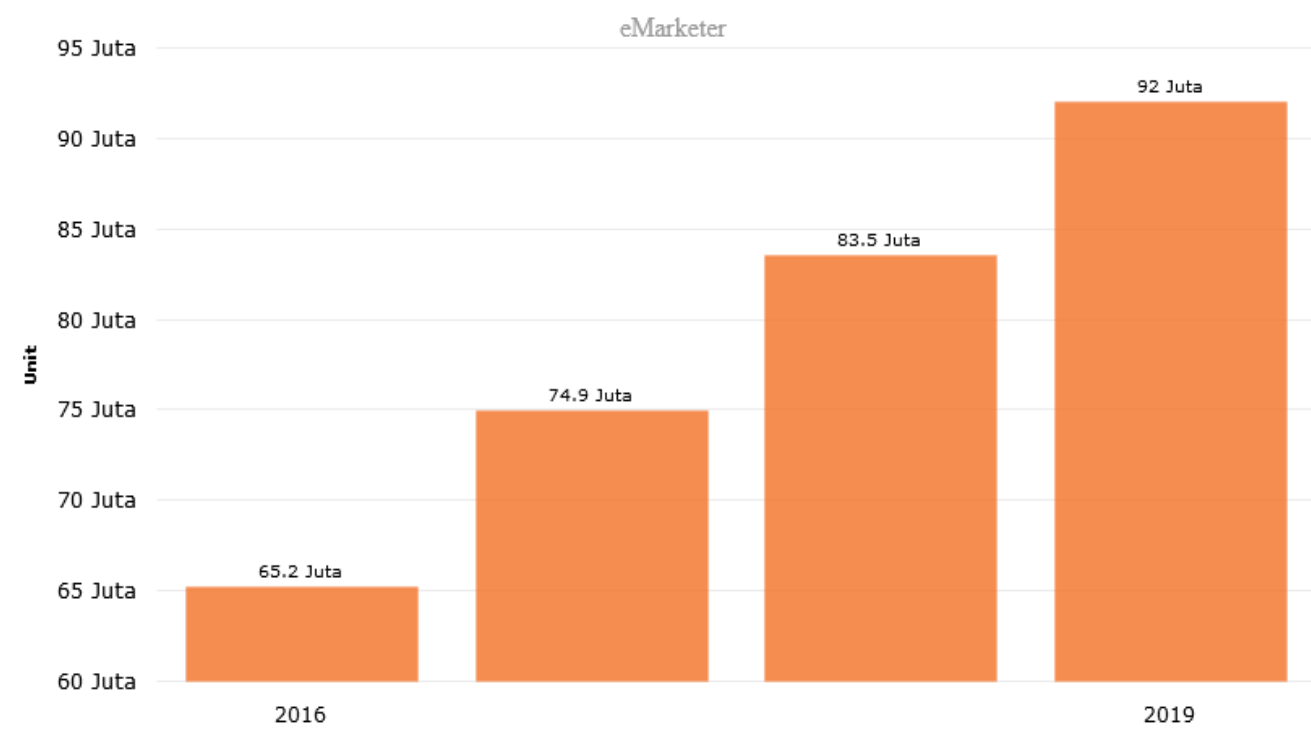

Gambar 1 Penggunaan Smartphone Tahun 2016 - 2019

Dari data diatas dapat dilihat bahwa penggunan smartphone dari tahun ke tahun mengalami peningkatan yang sangat signifikan. Pada tahun 2017 pengguna smartphone di Indonesia mencapat 74,9 juta dibandingkan dengan tahun sebelumnya 65,2 juta dan hal tersebut diprediksi akan terus mengalami peningkatan pada tahun-tahun yang akan datang menurut eMarketer, seiring dengan meningkatnya gaya hidup masyarakat modern, Indonesia kini telah menduduki peringkat keenam sebagai pengguna smartphone terbanyak di dunia (www.idntimes.com). Merek Xiaomi sudah mulai dikenal masyarakat Tiongkok sejak tahun 2011, mulai dikenal masyarakat Indonesia pada tahun 2013 dan mulai meledak dipasaran pada tahun 2014 dengan produk unggulannya yaitu smartphone Xiaomi. Smartphone Xiaomi menggunakan sistem operasi android dan sangat digemari oleh semua kalangan pada saat ini, hal ini dipengaruhi oleh tingkat promosi smartphone Xiaomi yang gencar dimedia sosial facebook melalui forum MI (Mobile Internet/Mission Impossible) Indonesia, strategi pemasaran yang baik, harga produk yang ditawarkan relatif terjangkau, tampilan yang cukup menarik dan memiliki performa yang cukup baik.

Dalam keputusan membeli barang konsumen seringkali melibatkan dua pihak dalam proses pertukaran atau pembelian. Umumnya ada lima macam peranan yang dapat dilakukan seseorang. Ada kalanya kelima peran ini dipegang oleh satu orang. Namun, seringkali peranan tersebut dilakukan oleh beberapa orang. Pemahaman mengenai masing-masing peranan ini sangat berguna dalam rangka memuaskan kebutuhan konsumen dan keinginan konsumen. Kelima peran tersebut meliputi, pemrakarsa (initiator), pemberi pengaruh (influencer), pengambilan keputusan (decider), pembeli (buyer), pemakai (user) (Kotler, 2015). Perilaku konsumen lain yang mesti dicatat adalah masalah pengambilan keputusan dalam pembelian. Pengambilan keputusan konsumen dalam pembelian smartphone oleh pertimbangan rasional yang sangat bertumpu pada funcional benefit. Konsumen pada saat ini lebih selektif dalam memilih produk yang akan digunakan karena banyaknya produk yang ditawarkan dan memiliki kelebihannya yang berbeda satu sama lain. Bagi konsumen, kualitas produk sering menjadi perhatian utama. Produk yang dikatakan berkualitas jika seluruh fungsinya dapat dijalankan dengan baik dan bermanfaat, (Kotler and Armstrong, 2008) menyatakan bahwa kualitas adalah salah 
satu alat untuk positioning menetapkan posisi bagi pemasar. Dalam memilih produk yang akan dibeli, konsumen akan mengevaluasi berbagai produk yang ditawarkan sebelum menetapkan keputusan pembelian. Melakukan penilaian terhadap suatu produk agar dapat mengetahui produk tersebut benar-benar memiliki kualitas yang baik dan mampu memenuhi kebutuhannya dan fungsi yang ada mampu berfungsi dengan baik atau tidak. Hal ini membuat produsen harus lebih giat lagi untuk melakukan pendekatan kepada konsumen agar mengetahui apa yang konsumen inginkan dan berbagai macam perilaku konsumen. Oleh karena itu, pilihan konsumen dalam menggunakan smartphone saat ini sangatlah tinggi, hal ini dibuktikan dengan adanya peningkatan penjualan produk smartphone yang berbasis android merek Xiaomi.

Persepsi harga yang dapat mempengaruhi seseorang dalam mengambil keputusan, persepsi harga dapat didefinisikan sebagai suatu proses dimana seorang menyeleksi dan mengorganisasikan dalam suatu gambaran yang berarti menyeluruh. Persepsi harga merupakan unsur bauran pemasaran yang fleksibel, artinya dapat diubah dengan cepat sesuai keadaan. Persepsi juga berpengaruh kuat pada konsumen. Secara umum, persepsi harga adalah salah satu pertimbangan penting dalam proses keputusan pembelian, dan kebanyakan konsumen mengevaluasi nilai (kombinasi antara harga dan kualitas) dalam keputusan pembelian. Penetapan harga oleh penjual akan berpengaruh terhadap perilaku pembelian konsumen, sebab harga yang dapat dijangkau oleh konsumen akan cenderung membuat konsumen melakukan pembelian terhadap produk tersebut. Persepsi konsumen terhadap harga dapat mempengaruhi keputusannya dalam membeli suatu produk. Oleh karena itu, setiap produsen akan berusaha memberikan persepsi yang baik terhadap produk yang mereka jual Kemunculan smartphone Xiaomi yang membuat pecinta gadget di Indonesia dibuat penasaran oleh smartphone tersebut. Dengan harga yang sangat bervariasi, mulai dari yang paling murah hingga yang termahal yaitu Rp. $750.000-\mathrm{Rp}$. 7.410.000 konsumen dapat membeli smartphone Xiaomi sesuai dengan budget dan kebutuhan mereka. Harga termurah dengan tipe Xiaomi Redmi 2, sedangkan yang termahal tipe Xiaomi Mi 8 (www.anonytun.com). Dengan berbagai kualitas produk yang ada, harga yang variatif serta promosi yang gencar diharapkan dapat meningkatkan keputusan pembelian.

Menurut Tjiptono (2014) mendefinisikan varian produk adalah suatu unit khusus dalam suatu merek atau lini produk yang dapat dibedakan berdasarkan ukuran, harga, penampilan, atau atribut lain, yang biasanya juga disebut stockkeeping atau variasi produk. Hubungan antara keragaman produk dan perilaku konsumen dalam melakukan keputusan pembelian sangat erat kaitannya pada kelangsungan penjualan suatu perusahaan. kondisi yang tercipta dari ketersediaan barang dalam jumlah dan jenis yang sangat variatif sehingga menimbulkan banyaknya pilihan dalam proses belanja konsumen. indikator dari Variasi produk menurut adalah : Corak, Kualitas, dan Desain. Fenomena menurut hasil wawancara penulis dengan 30 responden dari hasil 12 orang menyatakan bahwa harga yg ditawarkan tidak sebanding dengan kualitas yang ditawarkan dikarenakan berbagai alasan saat ini ada smartphone yang lebih baik dan 11 responden menyatakan masih ragu-ragu dalam melakukan pembelian smartphone xiaomi karena belum bisa meyakinkan dengan harga yang relative murah dengan kualitas yang cukup mumpuni. Maksud dan tujuan penelitian ini adalah :

1. Untuk mengetahui pengaruh persepsi harga produk Smarphone Xiaomi terhadap keputusan pembelian pada pengguna smartphone

2. Untuk mengetahui varian produk Smartphone Xiaomi terhadap keputusan pembelian pada pengguna smartphone

3. Untuk mengetahui kualitas produk terhadap keputusan pembelian pada pengguna smartphone

4. Untuk mengetahui persepsi harga, varian produk, dan keputusan pembelian pada pengguna smartphone
Customer Buying

Decision and

Product's Attributes 
Customer Buying

Decision and

Product's Attributes

\section{METODE PENELITIAN}

Lokasi penelitian ini adalah di Kampus Institut Bisnis dan Informatika Kesatuan Bogor yang berlokasi di Kota Bogor. Penelitian dilakukan mulai Januari sampai dengan Maret 2020. Data premier adalah data yang hanya dapat diperoleh dari sumber asli atau data pertama. Dalam penelitian ini, data premier diperleh melalui kuisoner yang dibagikan kepada Mahasiswa/i IBI Kesatuan Bogor dengan pertanyaan-pertanyaan seperti usia, jenis kelamin, pekerjaan dan lain-lain serta persepsi responden tentang Persepsi harga (X1) Varian produk (X2) Kualitas produk (X3) terhadap keputusan pembelian (Y). Populasi yang digunakan dalam penelitian ini adalah Mahasiswa/i di IBI Kesatuan Bogor yang menggunakan smartphone Xiaomi yang jumlahnya tidak teridentifikasi secara pasti. Sampel ditetapkan sebanyak 100 orang responden. Data dianalisis menggunakan analisis regresi berganda dengan sebelumnya dilakukan uji kualitas data mulai dari uji validitas, uji reliabilitas sampai dengan uji asumi klasik. Uji kualitas data tersebut menunjukkan bahwa data dapat dianalisis lebih lanjut menggunakan uji korelasi dan regresi berganda.

Hipotesis penelitian ini adalah sebagai berikut :

Pengaruh Persepsi Harga dengan keputusan Pembelian

H0 : : b1 = 0, Persepsi Harga tidak mempunyai hubungan dengan Keputusan Pembelian $\mathrm{H} 1: \mathrm{b} 1 \neq 0$, Persepsi Harga mempunyai hubungan dengan Keputusan Pembelian Pengaruh Varian Produk dengan Keputusan Pembelian $\mathrm{H} 0: \mathrm{b}_{2}=0$, Varian Produk tidak mempunyai hubungan dengan Keputusan Pembelian $\mathrm{H} 2: \mathrm{b}_{2} \neq 0$, Varian Produk mempunyai hubungan dengan Keputusan Pembelian Pengaruh Kualitas Produk dengan Keputusan Pembelian H0 : $b_{3}=0$, Kualitas Produk tidak mempunyai hubungan dengan keputusan pembelian $\mathrm{H} 3: b_{3} \neq 0$, Kualitas Produk mempunyai hubungan dengan keputusan pembelian Pengaruh Persepsi Harga, Varian Produk, dan Kualitas Produk Terhadap Keputusan Pembelian

H0 : $b_{1}, b_{2}, b_{3}=0$, Persepsi Harga, Varian Produk, dan Kualitas Produk tidak mempunyai pengaruh terhadap Keputusan Pembelian

H4 : $b_{1}, b_{2}, b_{3} \neq 0$, Persepsi Harga, Varian Produk, dan Kualitas Produk mempunyai pengaruh terhadap keputusan pembelian

\section{HASIL DAN PEMBAHASAN Profil Responden}

Responden penelitian ini mayoritas adalah Perempuan dengan jumlah responden mencapai 53 orang responden, sedangkan untuk responden laki-laki berjumlah 47 orang responden. Hal ini dikarenakan banyak konsumen yang menggunakan produk Xiaomi adalah perempuan. Berdasarkan semester responden, maka hasil yang didapatkan ialah 22 orang mahasiswa dan mahasiswa semester 2 IBIK Bogor, 18 orang mahasiswa dan mahasiswi semester 4 IBIK Bogor, 25 orang mahasiswa dan mahasiswi semester 6 IBIK Bogor, dan 35 orang mahasiswa dan mahasiswi semester 8 IBIK Bogor.

\section{Koefisien Korelasi}

Analisis Korelasi dimaksudkan untuk mengetahui seberapa besar hubungan antara variable dan bagaimana arah hubungan tersebut dengan besarnya koefisien korelasi antara +1 sampai dengan -1 . Tabel 1 menunjukkan bahwa hasil koefisien korelasi antara variable. Berdasarkan tabel 1, diketahui bahwa variabel persepsi harga (X1), varian produk (X2), kualitas produk (X3), dan keputusan pembelian (Y) mempunyai nilai Sig. kurang dari 0.05 atau $<5 \%$ sehingga dapat disimpulkan bahwa antar variabel memiliki korelasi satu sama lain dengan keterangan sebagai berikut:

1. Variabel persepsi harga (X1) berkorelasi positif sebesar 0,736 terhadap variabel varian produk (X2) dengan tingkat korelasi rendah; 0,641 terhadap variabel kualitas produk (X3) dengan tingkat korelasi sedang; dan 0,721 terhadap variabel keputusan pembelian (Y) dengan tingkat korelasi rendah. 
2. Variabel varian produk (X2) berkorelasi positif sebesar 0,736 terhadap variabel persepsi harga (X1) dengan tingkat korelasi rendah; 0,736 terhadap variabel kualitas produk (X3) dengan tingkat korelasi rendah; dan 0,771 terhadap variabel keputusan pembelian (Y) dengan tingkat korelasi sedang.

3. Variabel kualitas produk (X3) berkorelasi positif sebesar 0,641 terhadap variabel persepsi harga (X1) dengan tingkat korelasi sedang; 0,763 terhadap variabel varian produk (X2) dengan tingkat korelasi rendah; dan 0,719 terhadap variabel keputusan pembelian (Y) dengan tingkat korelasi sedang.

4. Variabel keputusan pembelian (Y) berkorelasi positif sebesar 0,721 terhadap variabel persepsi harga (X1) dengan tingkat korelasi rendah; 0,771 terhadap variabel varian produk (X2) dengan tingkat korelasi sedang; dan 0,719 terhadap variabel persepsi harga (X3) dengan tingkat korelasi sedang.

Tabel 1 Hasil Analisis Korelasi

\begin{tabular}{|c|c|c|c|c|c|}
\hline \multicolumn{6}{|c|}{ Correlations } \\
\hline & & $\begin{array}{c}\text { Persepsi } \\
\text { Harga }\end{array}$ & $\begin{array}{l}\text { Varian } \\
\text { Produk }\end{array}$ & $\begin{array}{l}\text { Kualitas } \\
\text { Produk }\end{array}$ & $\begin{array}{l}\text { Keputusan } \\
\text { Pembelian }\end{array}$ \\
\hline \multirow[t]{3}{*}{ Persepsi Harga } & Pearson Correlation & 1 & $.736^{* *}$ & $.641^{* *}$ & $.721^{* *}$ \\
\hline & Sig. (2-tailed) & & .000 & .000 & .000 \\
\hline & $\mathrm{N}$ & 100 & 100 & 100 & 100 \\
\hline \multirow{3}{*}{ Varian Produk } & Pearson Correlation & $.736^{* *}$ & 1 & $.763^{* *}$ & $.771^{* *}$ \\
\hline & Sig. (2-tailed) & .000 & & .000 & .000 \\
\hline & $\mathrm{N}$ & 100 & 100 & 100 & 100 \\
\hline \multirow[t]{3}{*}{ Kualitas Produk } & Pearson Correlation & $.641^{* *}$ & $.763^{* *}$ & 1 & $.719^{* *}$ \\
\hline & Sig. (2-tailed) & .000 & .000 & & .000 \\
\hline & $\mathrm{N}$ & 100 & 100 & 100 & 100 \\
\hline \multirow{3}{*}{$\begin{array}{l}\text { Keputusan } \\
\text { Pembelian }\end{array}$} & Pearson Correlation & $.721^{* *}$ & $.771^{\text {** }}$ & $.719^{* *}$ & 1 \\
\hline & Sig. (2-tailed) & .000 & .000 & .000 & \\
\hline & $\mathrm{N}$ & 100 & 100 & 100 & 100 \\
\hline
\end{tabular}

**. Correlation is significant at the 0.01 level (2-tailed).

Sumber : Hasil Penelitian, 2020 (Pengolahan Data SPSS)

\section{Koefisien Derteminasi}

Koefisien derteminasi dimaksud untuk mengetahui seberapa jauh variabel Persepsi Harga, Varian Produk, dan Kualitas produk terhadap Keputusan Pembelian.

Tabel 2 Nilai Korelasi Berganda dan Koefisien Determinasi

\begin{tabular}{|l|r|r|r|r|}
\hline Model & \multicolumn{1}{|c|}{$\mathrm{R}$} & R Square & Adjusted R Square & Std. Error of the Estimate \\
\hline 1 & $.821^{\mathrm{a}}$ & .673 & .663 & 2.223 \\
\hline
\end{tabular}

a. Predictors: (Constant), PERSEPSI HARGA, VARIAN PRODUK, KUALITAS PRODUK

b. Dependent Variable: Keputusan Pembelian

\section{Sumber : Hasil Penelitian, 2020 (Pengolahan Data SPSS)}

Analisis Korelasi dimaksudkan untuk mengetahui seberapa besar hubungan antara variable. Berdasarkan pada tabel 1 dapat dijelaskan bahwa hubungan atau korelasi berganda pada seluruh variabel kualitas fitur dan kemudahan mengakses mobile apps memiliki hubungan yang sedang. Hal ini berdasarkan nilai koefisien korelasi berganda sebesar 0,821. Perolehan nilai R Square sebesar 0,673 dapat dijelaskan bahwa variabel persepsi harga, varian produk, dan kualitas pembelian menjelaskan keragaman nilai dari keputusan pembelian para konsumen sebesar 67,3\% sedangkan sisanya sebesar 32,7\% dijelaskan oleh variabel lain yang tidak diteliti dengan penelitian ini.

\section{Analisis Regresi Berganda}

Selanjutnya dialakukan analisis regresi berganda untuk mengetahui pengaruh variable independent terhadap variable dependen baik secara parsial maupun secara simultan 
Customer Buying

Decision and Product's Attributes (bersama-sama). Untuk mengetahui pengaruh secara parsial, dilakukan uji t dengan hasil analisis sebagaimana terlihat pada Tabel 3.

Tabel 3 Hasil Uji Regresi secara parsial

\begin{tabular}{|c|c|c|c|c|c|}
\hline \multirow[b]{2}{*}{ Model } & \multicolumn{2}{|c|}{$\begin{array}{c}\text { Unstandardized } \\
\text { Coefficients } \\
\end{array}$} & \multirow{2}{*}{$\begin{array}{l}\text { Standardized } \\
\text { Coefficients } \\
\text { Beta }\end{array}$} & \multirow[b]{2}{*}{ t } & \multirow[b]{2}{*}{ Sig. } \\
\hline & B & Std. Error & & & \\
\hline \begin{tabular}{|ll}
1 & (Constant) \\
\end{tabular} & 3.708 & 1.497 & & -2.477 & .015 \\
\hline Persepsi Harga & .450 & .136 & 291 & 3.316 & .001 \\
\hline Varian Produk & .427 & .123 & .360 & 3.461 & .001 \\
\hline Kualitas Produk & .327 & .116 & .258 & 2.813 & .006 \\
\hline
\end{tabular}

a. Dependent Variable: Keputusan Pembelian

Berdasarkan hasil analisis regresi berganda, diperoleh persamaan regresi sebagai berikut:

$\mathrm{Y}=-3,708+0,450 \mathrm{X}_{1}+0.427 \mathrm{X}_{2}+0,327 \mathrm{X}_{3}+$ error

yang dapat diinterpretasikan bahwa:

Jika persepsi harga $=$ varian produk $=$ kualitas produk $=0$ maka keputusan pembelian nilainya sebesar 3,708 .

Jika persepsi harga naik sebesar 1 (satu) satuan maka keputusan pembelian akan naik sebesar 0,450 jika variabel lain di anggap konstan.

Jika varian produk naik sebesar 1 (satu) satuan maka keputusan pembelian akan naik sebesar 0,427 jika variabel lain di anggap konstan.

Jika kualitas produk naik sebesar 1 (satu) satuan maka keputusan pembelian akan naik sebesar 0,327 jika variabel lain di anggap konstan.

\section{Pengujian Hipotesis Pertama (H1)}

Pengaruh antara persepsi harga dengan keputusan pembelian

$\mathrm{H} 0: \beta 1=0$, artinya tidak terdapat pengaruh antara persepsi harga terhadap keputusan pembelian.

Ha : $\beta 1 \neq 0$, artinya terdapat pengaruh antara persepsi harga terhadap keputusan pembelian.

Diketahui nilai Sig. untuk pengaruh X1 (persepsi harga) terhadap Y (keputusan pembelian) adalah sebesar $0.001>1,98$ dan nilai t hitung 3,316 $<\mathrm{t}$ tabel 1.984 sehingga dapat disimpulkan bahwa $\mathrm{H} 1$ ditolak yang berarti tidak terdapat pengaruh X1 (persepsi harga) terhadap Y (keputusan pembelian).

\section{Pengujian Hipotesis Kedua (H2)}

Pengaruh antara varian produk dengan keputusan pembelian

$\mathrm{H} 0: \beta 2=0$, artinya tidak terdapat pengaruh antara varian produk terhadap keputusan pembelian.

Ha : $\beta 2 \neq 0$, artinya terdapat pengaruh antara kelengkapan produk terhadap keputusan pembelian.

Diketahui nilai Sig. untuk pengaruh X2 (varian produk) terhadap Y (keputusan pembelian) adalah sebesar $0.001<1,98$ dan nilai t hitung 3,461 $>\mathrm{t}$ tabel 1.984 sehingga dapat disimpulkan bahwa H2 diterima yang berarti terdapat pengaruh X2 (kualitas produk) terhadap Y (keputusan pembelian).

\section{Pengujian Hipotesis Ketiga (H3)}

Pengaruh antara kualitas produk dengan keputusan pembelian

$\mathrm{H} 0: \beta 3=0$, artinya tidak terdapat pengaruh antara kualitas produk terhadap keputusan pembelian.

Ha : $\beta 3 \neq 0$, artinya terdapat pengaruh antara kualitas produk terhadap keputusan pembelian.

Diketahui nilai Sig. untuk pengaruh X3 (kualitas produk) terhadap Y (keputusan pembelian) adalah sebesar $0.006<1,98$ dan nilai t hitung 2,813 $>\mathrm{t}$ tabel 1.984 sehingga dapat disimpulkan bahwa H3 diterima yang berarti terdapat pengaruh X3 (kualitas produk) terhadap Y (keputusan pembelian). 
Tabel 4. Hasil Uji Regresi Secara Simultan

\begin{tabular}{|c|c|c|c|c|c|c|}
\hline & & $\begin{array}{l}\text { Sum of } \\
\text { Squares }\end{array}$ & $\mathrm{df}$ & Mean Square & $\mathrm{F}$ & Sig. \\
\hline \multirow[t]{3}{*}{1} & Regression & 977.525 & 3 & 325.842 & 65.927 & $.000^{\mathrm{b}}$ \\
\hline & Residual & 474.475 & 96 & 4.942 & & \\
\hline & Total & 1452.000 & 99 & & & \\
\hline
\end{tabular}

a. Dependent Variable: Keputusan Pembelian

b. Predictors: (Constant), Kualitas Produk, Persepsi Harga, Varian Produ

\section{Pengujian Hipotesis Keempat (H4)}

Hubungan antara persepsi harga, varian produk, dan kualitas produk dengan keputusan pembelian

$\mathrm{H} 0: \beta 1=\beta 2=\beta 3=0$, artinya tidak terdapat pengaruh signifikan antara X1 (persepi harga), X2 (varian produk), dan X3 (kualitas produk) secara simultan terhadap Y (keputusan pembelian).

Ha : $\beta 1 \neq \beta 2 \neq \beta 3 \neq 0$, artinya terdapat pengaruh signifikan antara X1 (persepsi harga), X2 (varian produk), dan X3 (kualitas produk) secara simultan terhadap Y (keputusan pembelian).

Diketahui nilai Sig. untuk pengaruh X1 (persepsi harga), X2 (varian produk), dan X3 (kualitas produk) secara simultan terhadap Y (keputusan pembelian) adalah sebesar 0.000 $<1,98$ dan nilai $\mathrm{F}$ hitung 65,927 > F tabel 3,09 sehingga dapat disimpulkan bahwa H4 diterima yang berarti terdapat pengaruh X1 (persepsi harga), X2 (varian produk), dan X3 (kualitas produk) secara simultan terhadap Y (keputusan pembelian)

\section{Pembahasan}

Berdasarkan hasil kuisoner dan pengolahan data kuisoner menggunakan program SPSS yang telah dilakukan, maka pembahasan terhadap hipotesis penelitian adalah sebagai berikut :

Pengaruh Persepsi Harga (X1) Terhadap Keputusan Pembelian (Y)

Berdasarkan hasil penelitian terhadap variabel persepsi harga yang dapat dilihat pada tabel 4.21 diperoleh $t$ hitung sebesar 3,316 > t tabel 1.984 dan nilai signifikansi sebesar $0.001<1,98$ sehingga dapat disimpulkan bahwa $\mathrm{H} 0$ ditolak dan $\mathrm{H} 3$ diterima yang berarti variabel persepsi harga berpengaruh positif dan signifikan secara parsial terhadap variabel keputusan pembelian pada pengguna Smartphone Xiaomi. Hasil penelitian ini relevan dengan penelitian terdahulu yang telah dilakukan sebelumnya, menurut Kotler dan Keller (2012) harga adalah satu elemen bauran pemasaran yang menghasilkan pendapatan, elemen lain menghasilkan biaya. Harga merupakan elemen termudah dalam program pemasaran untuk disesuaikan, fitur produk, saluran, dan bahkan komunikasi membutuhkan banyak waktu. Campbell pada Cockril dan Goode (2010) menyatakan bahwa persepsi harga merupakan faktor psikologis dari berbagai segi yang mempunyai pengaruh yang penting dalam reaksi konsumen kepada harga. Karena itulah persepsi harga menjadi alasan mengapa seseorang membuat keputusan untuk membeli. Xia et al. pada Lee dan Lawson-Body (2011) mengemukakan bahwa persepsi harga merupakan penilaian konsumen

Pengaruh Varian Produk (X2) Terhadap Keputusan Pembelian (Y)

Berdasarkan hasil penelitian terhadap variabel varian produk yang dapat dilihat pada tabel 4.21 diperoleh t hitung sebesar 3,461 > t tabel 1.984 dan nilai signifikansi sebesar $0.001<1,98$ sehingga dapat disimpulkan bahwa $\mathrm{H} 0$ ditolak dan $\mathrm{H} 2$ diterima yang berarti variabel kelengkapan produk berpengaruh positif dan signifikan secara parsial terhadap variabel keputusan pembelian pada pengguna Smartphone Xiaomi. Menurut Fandy tjiptono (2008) yaitu suatu unit khusus dalam suatu merek atau lini produk yang dapat dibedakan bedasarkan ukuran, harga, penampilan, atau atribut lainnya. biasanya disebut pula stock keeping unit atau variasi produk.
Customer Buying

Decision and

Promotional Mix

101 
Customer Buying

Decision and

Product's Attributes
Pengaruh Kualitas Produk (X3) Terhadap Keputusan Pembelian (Y)

Berdasarkan hasil penelitian terhadap variable kualitas produk yang dapat dilihat pada tabel 4.21 diperoleh $\mathrm{t}$ hitung sebesar 2,813 > t tabel 1.984 dan nilai signifikansi sebesar $0.006<1,98$ sehingga dapat disimpulkan bahwa $\mathrm{H} 0$ ditolak dan $\mathrm{H} 3$ diterima yang berarti variabel persepsi harga berpengaruh positif dan signifikan secara parsial terhadap variabel keputusan pembelian pada pengguna Smartphone Xiaomi. Kualitas adalah semua ciri dan karakteristik produk atau jasa yang kemampuannya dapat memuaskan kebutuhan, baik yang dinyatakan secara tegas maupun tersamar. Menurut ASQC (American Society for Quality Control) (dalam Amiruddin, 2007) Kualitas ialah gambaran total sifat dari suatu produk atau jasa pelayanan yang berhubungan dengan kemampuannya untuk memberikan kebutuhan kepuasan. Menurut Kotler dan Armstrong (2007) Kualitas Produk adalah kemampuan suatu produk untuk melakukan fungsi - fungsinya; kemampuan itu meliputi daya tahan, kehandalan, ketelitian yang dihasilkan, kemudahan dioperasikan dan diperbaiki, dan atribut lain yang berharga pada produk secara keseluruhan.

Pengaruh Persepsi Harga (X1), Varian Produk (X2), dan Kualitas Produk (X3) Terhadap Keputusan Pembelian (Y)

Berdasarkan hasil penelitian uji $\mathrm{F}$ yang dapat dilihat pada tabel 4.22 diperoleh $\mathrm{F}$ hitung sebesar 65,927 > F tabel 3,09 dan nilai signifikansi sebesar $0.000<1,98$ sehingga dapat disimpulkan bahwa $\mathrm{H} 0$ ditolak dan $\mathrm{H} 4$ diterima yang berarti variabel persepsi harga, varian produk, kualitas produk dan keputusan pembelian berpengaruh positif dan signifikan secara simultan terhadap variabel keputusan pembelian pada pengguna smartphone xiaomi. Perolehan nilai $R$ Square sebesar 0,673 membuktikan bahwa variabelvariabel independen (persepsi harga, varian produk, dan kualitas produk) memiliki kemampuan sebesar 67,3\% dalam menjelaskan variasi variabel dependen (keputusan pembelian). Sedangkan untuk sisanya yang sebesar 32,7\% merupakan variabel-variabel independen lain yang tidak diteliti dan juga kemungkinan besar memiliki kemampuan untuk menjelaskan variasi variabel dependen. Oleh karena itu, jika perusahaan mampu mengkombinasikan persepsi harga, varian produk, dan kualitas produk dengan baik maka merek tersebut kemungkinan besar dapat meningkatkan keputusan pembelian di kalangan masyarakat.

\section{PENUTUP}

Beberapa kesimpulan penelitian ini adalah sebagai berikut :

1. Persepsi Harga berpengaruh secara positif dan signifikan terhadap Keputusan Pembelian, dilihat dari persamaan regresi sebesar 0,450 dan memiliki nillai signifikansi sebesar 0,001 .

2. Varian Produk berpengaruh secara positif dan signifikan terhadap Keputusan Pembelian, dilihat dari persamaan regresi sebesar 0,427 dan memiliki nilai signifikansi sebesar 0,001

3. Kualitas Produk berpengaruh secara positif tetapi tidak signifikan terhadap Keputusan Pembelian, dilihat dari persamaan regresi sebesar 0.327 dan memiliki nilai signifikan sebesar 0,06

4. Persepsi Harga, Varian Produk dan Kualitas Produk secara bersama-sama memiliki pengaruh yang positif dan signifikan terhadap Keputusan Pembelian, dengan $\mathrm{F}$ hitung yang sebesar 65,927 dan lebih besar dibandingkan dari F Tabel sebesar 3,09 dan nilai signifikansi sebesar 0,000. Artinya semakin baik Persepsi Harga, Varian Produk dan Kualitas Produk, maka Keputusan Pembelian akan semakin tinggi.

\section{DAFTAR PUSTAKA}

[1] Ali, Hasan . 2013. Marketing dan Kasus-Kasus Pilihan. Yogyakarta. CAPS (Center For Academic Publishing Service) 
[2] Binangkitsari, L., 2018. The Influence of Brand Equity Elements on Purchase Decision and Its Imlication on Customer Loyalty.

[3] Gendalasari, G.G. and Triandi, T., 2018. Potret Kinerja UMKM Sepatu Di Bogor

Dalam Berkompetisi Pada Perekonomian Di Indonesia. Jurnal Ilmiah Manajemen Kesatuan, 6(2), pp.102-108.

[4] Iriyadi, I., 2019. Prevention of Earnings Management through Audit Committee and Audit Quality in the Award-Winning and Non-Winning Companies. Journal of Accounting Research, Organization and Economics, 2(2), pp.155-169.

[5] Munawar, A., Syarif, R. and Morita, M., 2019. Persepsi Mahasiswa Atas Galeri Investasi Perguruan Tinggi dan Pengaruhnya Terhadap Minat Berinvestasi. JAS-PT (Jurnal Analisis Sistem Pendidikan Tinggi Indonesia), 3(2), pp.89-96.

[6] Purba, J.H.V., Ratodi, M., Mulyana, M., Wahyoedi, S., Andriana, R., Shankar, K. and Nguyen, P.T., 2019. Prediction Model in Medical Science and Health Care. International Journal of Engineering and Advanced Technology, 8, pp.815-818.

[7] Setiawan, B., Panduwangi, M. and Sumintono, B., 2018. A Rasch analysis of the community's preference for different attributes of Islamic banks in Indonesia. International Journal of Social Economics.

[8] Wibowo, W. and Mekaniwati, A., 2020. Pengaruh Struktur Modal dan Kemampulabaan Terhadap Return Saham Perusahaan Properti dan Real Estate Yang Terdaftar di BEI Tahun 2013-2015. Jurnal Ilmiah Manajemen Kesatuan, 8(1), pp.19-28.

[9] Zuhdi, S., Rainanto, B.H. and Apriyani, D., 2020, May. Analysis of Co-Branding Strategy to Improve Company's Competitive Power (Case Study on Walls Selection Oreo). In 2nd International Seminar on Business, Economics, Social Science and Technology (ISBEST 2019) (pp. 146-149). Atlantis Press.

[10] Kotler 2015, "Marketing an Introducing Prentice Hall twelfth edition", England : Pearson Education, Inc

[11] Kotler, Philip and Gary Armstrong. 2008. Prinsip-prinsip Pemasaran. Edisi 12 Jilid 1. Jakarta: Erlangga.

[12] Fandy Tjiptono. 2014. Pemasaran Jasa (Prinsip, Penerapan, Penelitian). Yogyakarta. Andi

[13] Engel et al dalam Sangadji, E.M., dan Sopiah. 2013. Prilaku Konsumen: Pendekatan Praktis Disertai:Himpunan Jurnal Penelitian. Yogyakarta: Penerbit Andi

[14] Griffin dalam Sangadji, E.M., dan Sopiah. 2013. Prilaku Konsumen: Pendekatan Praktis Disertai:Himpunan Jurnal Penelitian. Yogyakarta: Penerbit Andi.

[15] Schiffman, L., \& Kanuk, L.L. dalam Sumarwan (2010). Consumer Behavior. 10th Edition. New Jersey: Pearson Prentice Hall.

[16] Kotler dan Keller. 2009. Manajemen Pemasaran. Jilid I. Edisi ke 13 Jakarta: Erlangg.

[17] Danang, Sunyoto. 2012. Manajemen Sumber Daya Manusia. Jakarta: PT Buku Seru.

[18] Sangadji, E.M., dan Sopiah. 2013. Prilaku Konsumen: Pendekatan Praktis Disertai:Himpunan Jurnal Penelitian. Yogyakarta: Penerbit Andi.

[19] Kotler, Philip 2008. Manajemen Pemasaran, Terjemahan : Bob Sabran. Edisi 13 Jilid 1. Erlangga, Jakarta

[20] Kotler dan Keller, 2012, Marketing Management Edisi 14, Global Edition.Pearson Prentice Hall.

[21] Fandy Tjiptono, 2012, Service Management Meningkatkan Layanan Prima, Jakarta : Andi

[22] Campbell pada Cockril dan Goode (2010) Biologi Edisi Kedelapan jilid 3(Terjemahan Oleh Damaring Tyas Wulandari). Jakarta: Erlangga

[23] Zeithaml dalam Kusdyah, 2012. Persepsi Harga, Persepsi Merek, Persepsi Nilai Dan Keinginan Pembelian Ulang Jasa Klinik (Studi Kasus Erha Clinic Surabaya). Jurnal Manajemen. Vol.7, No.1 April 2012. ISSN 1907- 235X.

[24] Fandy Tjiptono, 2008, Strategi Pemasaran. Yogyakarta, ANDI. 
Customer Buying

Decision and

Product's Attributes

104
[25] Hani handoko, 2004, Manajemen, edisi kedua, BPFE UGM Yogyakarta.

[26] ASQC (American Society for Quality Control) 2007

[27] Kotler and Armstrong Gary. (2007). Marketing An Introduction.Baba Barkha Nath Printers: New Delhi.

[28] Philip Kotler, 2002, Manajemen Pemasaran, Edisi Millenium, Jilid 2, PT Prenhallindo, Jakarta

[29] Augusty Ferdinand, Metode Penelitian Manajemen: Pedoman Penelitian untuk Skripsi, Tesis dan Disertasi Ilmu Manajemen, Semarang: Badan Penerbit Universitas Diponegoro. 2006

[30] Schiffman, Leon G. And Leslie L. Kanuk. 2000. Consumer Behavior. Fifth Edition, Prentice-Hall Inc. New Jersey

[31] Ghozali, Imam . (2011). Aplikasi Analisis Multivariate Dengan Program IBM SPSS 19 (edisi kelima.) Semarang: Universitas Dipenogoro.

[32] Augusty Ferdinand. 2011, Metode Penelitian Manajemen Pedoman Penelitian untuk Penulisan Skripsi, Tesis, dan Disertasi Ilmu Manajemen, Edisi 3, AGF Books, Fakultas Ekonomika dan Bisnis Universitas Diponegoro, Semarang.

[33] Ghozali, Imam. 2013. Aplikasi Analisis Multivariate dengan Program SPSS. Edisi Ketujuh. Semarang : Badan Penerbit Universitas Dipenogoro.

[34] Ghozali, Imam. 2009. "Aplikasi Analisis Multivariate dengan Program SPSS “. Semarang : UNDIP. 